Healthcare Nursing Journal Fakultas Ilmu Kesehatan UMTAS

E-ISSN : 2655-6812, Volume 2 Nomor 1, Agustus 2019

http://journal.umtas.ac.id/index.php/healtcare

\title{
Gambaran Behavioral Problems Pada Anak-anak Korban Kekerasan Seksual di Kecamatan Singaparna Wilayah Kerja P2TP2A Kabupaten Tasikmalaya
}

\author{
Neni Sholihat \\ Universitas Muhammadiyah Tasikmalaya \\ Email: nsholihat@gmail.com
}

\begin{abstract}
ABSTRAK
Kekerasan seksual, terutama pada anak-anak, seringkali dikatakan akan menimbulkan dampak dan trauma yang tidak ringan, serta bersifat jangka panjang. Penelitian ini bermaksud untuk mengidentifikasi dan menelaah apakah peristiwa kekerasan seksual yang dialami oleh tujuh orang anak di dua desa yang ditangani oleh P2TP2A Kabupaten Tasikmalaya pada tahun 2017, meninggalkan trauma pada korbannya atau tidak, dengan mengidentifikasi adanya perubahan perilaku pada korban yang diamati oleh orang tuanya masing-masing. Metode yang digunakan dalam penelitian ini adalah deskriptif survey. Sumber data dikumpulkan melalui asesmen psikologi meliputi observasi, wawancara, dan tes tertulis menggunakan PSC-17 dan Anatomical Drawing serta Gingerbread Figure untuk screening tingkat trauma berdasarkan ada tidaknya perubahan perilaku pada korban yang dikaitkan dengan adanya gangguan kesehatan mental menurut PSC-17. Data dikumpulkan selama konseling psikologi yang dilakukan oleh peneliti terhadap mereka. Hasil penelitian menunjukkan seluruh anak mengindikasikan adanya perubahan perilaku terkait kesehatan mentalnya, setelah mengalami peristiwa tersebut, meskipun sebagian besar anak sudah tidak merasakan sakit secara fisik di area genitalianya.
\end{abstract}

Kata Kunci: Anak, Kekerasan Seksual, Trauma, PSC-17, Anatomical Drawing, Ginger bread Figure, Gangguan Perilaku

\section{PENDAHULUAN}

Angka kejadian kasus kekerasan pada anak secara global, berdasarkan data dari official Journal on The American Academic of Pediatrics pada tahun 2016, menyatakan rata-rata $50 \%$ atau diperkirakan lebih dari 1 milyar anakanak di dunia berusia 2-17 tahun mengalami kekerasan fisik, seksual, emosional dan penelantaran, di kawasan Afrika, Asia, dan Amerika Utara dalam satu tahun terakhir. Sementara situasi nasional di Indonesia sendiri, berdasarkan laporan UNICEF tahun 2015, terjadi kekerasan secara luas yang menimpa anak-anak. Sebanyak 40\% anak berusia 13-15 tahun melaporkan pernah mendapatkan 
serangan secara fisik sedikitnya satu kali dalam setahun, $26 \%$ pernah mendapatkan hukuman fisik, dan 50\% melaporkan mengalami perundungan di sekolah. Hasil penelitian mengenai kekerasan seksual oleh Balai Besar Penelitian dan Pengembangan Pelayanan Kesejahteraan Sosial Yogyakarta (B2P3KS) Kementrian Sosial bekerja sama dengan End Child Prostitution, Child Pornography and Trafficking of Children for Sexual Purposes (ECPAT) pada tahun $2017 \mathrm{di}$ Jakarta Timur, Magelang, Jogja, Mataram dan Makasar terhadap 49 anak yang mengalami kekerasan seksual, menyatakan bahwa: $1 . \quad 50 \%$ kasus kekerasan seksual pada anak dilakukan oleh anak-anak, 2. Pelaku kekerasan seluruhnya laki-laki dan berusia ratarata 16 tahun, 3. 76\% kekerasan seksual dilakukan dengan paksaan, 4. 30\% bentuk kekerasan berupa sentuhan/rabaan di organ genital, dan $26 \%$ berupa hubungan badan (Infodatin Kementrian Kesehatan RI 2018).

Kejadian kekerasan seksual pada anak di Indonesia, mencapai puncaknya di tahun 2013, hingga ditetapkan sebagai darurat kekerasan seksual pada anak oleh Presiden Republik Indonesia. Dari tahun ke tahun berdasarkan laporan kementrian perempuan dan perlindungan anak, angka kejadian kekerasan pada anak terus meningkat, dan prosentase terbanyak adalah kekerasan seksual. Data menurut Komisi Perlindungan Anak Indonesia (KPAI) hingga tahun 2014, berdasarkan klasternya, kasus kekerasan seksual pada anak merupakan kasus yang tertinggi dibandingkan klaster lainnya, yang mencapai 2286 Kasus (Wahyuni, 2016). Kenyataan ini menunjukkan bahwa anak-anak Indonesia cukup rentan mengalami kekerasan seksual.

Di Kabupaten Tasikmalaya sendiri, sejak tahun 2010 telah dibentuk Pusat Pelayanan Terpadu Pemberdayaan Perempuan dan Anak (P2TP2A). P2TP2A Merupakan salah satu bentuk wahana pelayanan dalam upaya pemenuhan kebutuhan peningkatan pendidikan kesehatan, ekonomi, penanggulangan tindak kekerasan terhadap perempuan dan perlindungan anak serta peningkatan posisi dan kondisi perempuan dalam masyarakat. Latar belakang dibentuknya P2TP2A di Tasikmalaya adalah: 1. Tingginya angka kemiskinan 2. Tingginya kasus KDRT 3. Tingginya kasus Perdagangan Orang 4. Tingginya kasus pelecehan terhadap anak dan remaja dan 5 . 
Healthcare Nursing Journal Fakultas Ilmu Kesehatan UMTAS

E-ISSN : 2655-6812, Volume 2 Nomor 1, Agustus 2019

http://journal.umtas.ac.id/index.php/healtcare

Tingginya kasus kekerasan terhadap perempuan dan anak.

Sejak berdiri hingga penelitian ini dilakukan, P2TP2A Kabupaten Tasikmalaya telah menangani kurang lebih 100 kasus, dengan jenis kasus yang beragam. Diantara kasus-kasus tersebut adalah kasus perdagangan manusia (trafficking), kasus kekerasan dalam rumah tangga (KDRT), kasus penelantaran anak, dan kasus pelecehan atau kekerasan seksual pada anak. Prosentase tertinggi adalah kasus pelecehan dan kekerasan seksual pada anak. Pada periode pertama kepengurusan P2TP2A Kabupaten Tasikmalaya (2010-2017), diantara salah satu kasus kekerasan seksual pada anak yang ditangani dan menyita perhatian hingga menjadi bahasan media dan pemerintah secara nasional adalah peristiwa sodomi yang dilakukan oleh seorang guru mengaji kepada puluhan orang muridnya di Sukahening Nagrak Kecamatan Singaparna. Dengan didampingi oleh P2TP2A, para korban dan keluarga menjalani proses pendampingan dan pemulihan. Sementara untuk pelaku, dengan pengawasan tim advokasi P2TP2A bekerja sama dengan jaksa, memastikan ia mendapat hukuman yang setimpal.
Pada periode kepengurusan kedua (2017-2022), salah satu kasus yang cukup besar dan menimbulkan banyak korban adalah peristiwa sodomi yang terjadi di dua desa di kecamatan Singaparna, dimana korbannya adalah 7 orang anak yang mengalami sodomi oleh pelaku yang baru berusia 15 tahun. Penelitian ini membahas mengenai kondisi tujuh orang korban kekerasan seksual yang terjadi pada tahun 2017.

Anak-anak yang menjadi korban kekerasan seksual menghadapi resiko mengalami gangguan stres pascatrauma atau Post Traumatic Stress Disorder (PTSD). Wisdom CS (2000) mengatakan bahwa dampak pelecehan seksual pada anak akan mengakibatkan PTSD, bahkan Anne Caroline Drake (2015) mengatakan bahwa korban kekerasan seksual sebanyak 50\% sangat mungkin untuk mengalami PTSD (Wahyuni, 2016). PTSD sendiri didefinisikan sebagai suatu kejadian atau beberapa kejadian trauma yang dialami atau disaksikan secara langsung oleh seseorang berupa kematian, cedera fisik dan ancaman terhadap integritas fisik atas diri seseorang. Kejadian tersebut harus menciptakan ketakutan yang ekstrim, horor, dan rasa tidak berdaya. 
Dampak langsung yang biasanya tampak pada anak-anak korban kekerasan seksual diantaranya adalah gangguan emosi dan adanya perubahan perilaku terkait kesehatan mental mereka. Meskipun kekerasan seksual pada anak tidak selalu menunjukkan adanya bukti mutlak berupa luka fisik, namun jika terjadi perubahan perilaku yang muncul pada anak terus menerus dalam jangka waktu panjang, keluarga perlu mempertimbangkan kemungkinan adanya indikasi trauma yang dialami anak tersebut. Diantara perubahan perilaku tersebut menurut Jeane Wess dalam buku Slayer of The Soul (1991) adalah perilaku regresif seperti mengisap jempol, hiperaktif, keluhan somatik seperti sakit kepala terus menerus, keluhan sembelit, sakit perut, lalu tanda perilaku emosional dan sosial seperti perilaku yang tiba-tiba berubah, keluhan rasa sakit karena pelecehan seksual, merasa terancam, tertekan, gelisah dan cemas (Sari dll, 2015)

\section{METODE}

Penelitian ini menggunakan pendekatan metoda deskriptif survey dengan subjek penelitian adalah anak-anak korban kekerasan seksual yang ditangani oleh P2TP2A Kabupaten Tasikmalaya sebanyak tujuh orang, berasal dari dua desa di kecamatan Singaparna Kabupaten Tasikmalaya pada tahun 2017. Adapun instrumen yang digunakan dalam penelitian ini adalah observasi terhadap anak, wawancara kepada orang tua dan asesmen psikologi untuk mengetahui adanya masalah perilaku setelah kejadian pada korban kekerasan seksual dengan menggunakan Pediatric Symptom Checklist (PSC -17), Anatomical Drawing dan Gingerbread Figure.

Pediatric Symptom Checklist (PSC-17) adalah instrumen yang digunakan sebagai screening untuk melihat ada tidaknya masalah perilaku yang diakibatkan oleh berbagai peristiwa yang dialami oleh anak, dalam hal ini peristiwa kekerasan seksual. PSC-17 dikembangkan oleh W. Gardner dan K. Kelleher (1999) berdasarkan pengembangan dari PSC yang dikembangkan oleh M. Jellinek et.al (1988). Instrumen ini terdiri dari 17 perilaku yang ditanyakan kepada pendamping ataupun orang tua korban, untuk diberi skor dalam bentuk frekuensi tidak pernah (diberi skor 0), kadang-kadang (diberi skor 1) dan sering (diberi skor 2). Perilaku yang ditanyakan memiliki tiga kategori yaitu 
Healthcare Nursing Journal Fakultas Ilmu Kesehatan UMTAS

E-ISSN : 2655-6812, Volume 2 Nomor 1, Agustus 2019

http://journal.umtas.ac.id/index.php/healtcare

Internalizing (I), Attention (A) dan

Externalizing (E). Contoh perilaku yang termasuk kedalam Internalizing adalah kecemasan dan depresi. Perilaku yang termasuk kedalam kategori Attention adalah Attention Deficit Disorder $(A D D)$ atau gangguan pemusatan perhatian dan Attention Deficit and Hiperactivity Disorder (ADHD) atau gangguan pemusatan perhatian disertai hiperaktivitas. Sementara yang termasuk kedalam Externalizing dan adalah perilaku melanggar aturan atau perilaku yang mengganggu hak-hak orang lain. Adapun Cut off untuk skor I adalah $\geq 5$, cut off untuk skor A adalah $\geq 7$ dan cut off untuk skor E juga $\geq 7$, dengan skor total $\geq 15$. Skor yang lebih tinggi dari cut off menunjukkan adanya gejala gangguan kesehatan mental (behavior health disorder), yang dalam penelitian ini dikaitkan dengan kondisi trauma pasca mengalami kekerasan seksual. Instrumen yang digunakan oleh peneliti sudah diterjemahkan oleh Pusat Bahasa Fakultas Ilmu Budaya Universitas Airlangga Surabaya.

Anatomical drawing dan gingerbread figure adalah gambar yang digunakan untuk menggali ada tidaknya peristiwa kekerarasan seksual pada anak, tanpa meminta anak untuk menceritakan kembali peristiwanya. Tujuannya agar anak terhindar dari keharusan mengingat kembali peristiwa yang dialaminya, sehingga tidak menimbulkan trauma yang semakin mendalam, akibat terus menerus mengulang-ulang cerita yang sama. Yang dilakukan anak adalah memberi tanda pada kedua gambar tersebut bagian tubuh yang dirasakan sakit ataupun bagian tubuh yang menerima kekerasan seksual dari pelaku.

\section{HASIL}

Hasil dari asesmen behaviorl problems dengan menggunakan instrumen PSC-17 disajikan dalam tabel berikut:

\begin{tabular}{|l|l|l|l|l|l|}
\hline No & $\begin{array}{c}\text { Inisial/ } \\
\text { Jenis } \\
\text { Kelamin }\end{array}$ & Usia & Pendidikan & $\begin{array}{c}\text { Jumlah } \\
\text { kekerasan } \\
\text { seksual yang } \\
\text { dialami }\end{array}$ & SKOR PSC-17 \\
\hline 1 & R/L & $\begin{array}{l}10 \\
\text { tahun }\end{array}$ & Kelas IV & 2 kali & $\begin{array}{l}\mathrm{I}=4 \\
\mathrm{~A}=6 \\
\mathrm{E}=5\end{array}$ \\
\hline
\end{tabular}


Healthcare Nursing Journal Fakultas Ilmu Kesehatan UMTAS

E-ISSN : 2655-6812, Volume 2 Nomor 1, Agustus 2019

http://journal.umtas.ac.id/index.php/healtcare

\begin{tabular}{|c|c|c|c|c|c|}
\hline & & & & & Skor total $=15$ \\
\hline 2 & $\mathrm{G} / \mathrm{L}$ & $\begin{array}{l}7 \\
\text { tahun }\end{array}$ & Kelas I & 2 kali & $\begin{array}{l}I=5 \\
A=5 \\
E=6 \\
\text { Skor total }=16\end{array}$ \\
\hline 3 & $\mathrm{~A} / \mathrm{L}$ & $\begin{array}{l}7 \\
\text { tahun }\end{array}$ & Kelas I & $1 \mathrm{kali}$ & $\begin{array}{l}I=5 \\
A=6 \\
E=6 \\
\text { Skor Total }-17\end{array}$ \\
\hline 4 & $\mathrm{D} / \mathrm{L}$ & $\begin{array}{l}7 \\
\text { tahun }\end{array}$ & Kelas I & 1 kali & $\begin{array}{l}I=5 \\
A=8 \\
E=5 \\
\text { Skor total }=18\end{array}$ \\
\hline 5 & $\mathrm{~K} / \mathrm{L}$ & $\begin{array}{l}7 \\
\text { tahun }\end{array}$ & Kelas I & 1 kali & $\begin{array}{l}I=4 \\
A=6 \\
E=7 \\
\text { Skor total }=17\end{array}$ \\
\hline 6 & $\mathrm{~V} / \mathrm{L}$ & $\begin{array}{l}7 \\
\text { tahun }\end{array}$ & Kelas I & 2 kali & $\begin{array}{l}I=8 \\
A=9 \\
E=9 \\
\text { Skor total }=26\end{array}$ \\
\hline 7 & $\mathrm{AR} / \mathrm{L}$ & $\begin{array}{l}9 \\
\text { tahun }\end{array}$ & Kelas III & 2 kali & $\begin{array}{l}I=6 \\
A=9 \\
E=7 \\
\text { Skor total }=22\end{array}$ \\
\hline
\end{tabular}

Tabel1. Hasil Asesmen PSC-17

Berdasarkan tabel diatas, seluruh korban menunjukkan hasil skor total diatas cut off $\geq 15$. Berarti seluruh korban menunjukkan adanya gejala perubahan perilaku terkait kesehatan mentalnya akibat mengalami peristiwa kekerasan seksual yang dialami. Skor cut off terkecil ditunjukkan oleh korban pertama, dan skor cut off terbesar ditunjukkan oleh dua korban terakhir. Dua korban terakhir, baru mengalami kekerasan seksual dua hari sebelum dibawa menemui peneliti, sehingga perubahan perilaku akibat peristiwa tersebut masih banyak muncul berdasarkan jawaban yang diberikan orang tuanya saat menjawab pernyataan pada item-item PSC-17. Observasi dan wawancara pada korban kekerasan seksual bertujuan untuk melihat kondisi anak secara langsung, apakah memungkinkan untuk dilakukan asesmen, yang terlihat dari perilaku dan kondisi emosionalnya, apakah anak cukup kooperatif dan mampu berkomunikasi dengan baik serta memahami apa yang disampaikan oleh peneliti, dalam arti secara kognitif anak 
Healthcare Nursing Journal Fakultas Ilmu Kesehatan UMTAS

E-ISSN : 2655-6812, Volume 2 Nomor 1, Agustus 2019

http://journal.umtas.ac.id/index.php/healtcare

bisa memahami dan menjawab

Hasil observasi dan wawancara dengan

pertanyaan yang disampaikan dengan para korban disajikan dalam tabel

baik. Interview juga bermaksud berikut:

memahami apakah anak mengerti

mengenai peristiwa kekerasan seksual

yang dialaminya.

\begin{tabular}{|c|c|c|c|c|c|}
\hline No & $\begin{array}{l}\text { Inisial/ } \\
\text { Jenis } \\
\text { Kelamin }\end{array}$ & Usia & Pendidikan & Observasi & Wawancara \\
\hline 1 & $\mathrm{R} / \mathrm{L}$ & $\begin{array}{l}10 \\
\text { tahun }\end{array}$ & Kelas IV & $\begin{array}{l}\text { Cukup } \\
\text { komunikatif, } \\
\text { bersedia } \\
\text { bercerita } \\
\text { dirinya rentang } \\
\text { kegiatan sehari- } \\
\text { hari dan } \\
\text { dilakukan yang } \\
\text { dengan ekspresif }\end{array}$ & $\begin{array}{l}\text { Mengerti apa nama } \\
\text { peristiwa kekerasan } \\
\text { yang dialami } \\
\text { Tidak mengerti } \\
\text { makna peristiwa } \\
\text { kekerasan seksual } \\
\text { yang dialami }\end{array}$ \\
\hline 2 & $\mathrm{G} / \mathrm{L}$ & $\begin{array}{l}7 \\
\text { tahun }\end{array}$ & Kelas I & $\begin{array}{l}\text { Banyak } \\
\text { menunduk, } \\
\text { bersedia } \\
\text { bercerita tentang } \\
\text { dirinya, namun } \\
\text { dengan jawaban } \\
\text { yang singkat }\end{array}$ & $\begin{array}{lr}\text { Tidak } & \text { mengerti } \\
\text { nama dan makna } \\
\text { peristiwa } & \text { kekerasan } \\
\text { seksual } & \text { yang } \\
\text { dialami } & \end{array}$ \\
\hline 3 & $\mathrm{~A} / \mathrm{L}$ & $\begin{array}{l}7 \\
\text { tahun }\end{array}$ & Kelas I & \begin{tabular}{l} 
Cukup \\
komunikatif, \\
bersedia \\
bercerita \\
dirinya rentang \\
kegiatan sehari- \\
hari dan \\
dilakukan yang \\
\multicolumn{2}{l}{ dengan ekspresif }
\end{tabular} & $\begin{array}{lr}\text { Tidak } & \text { mengerti } \\
\text { nama dan makna } \\
\text { peristiwa } & \text { kekerasan } \\
\text { seksual } & \text { yang } \\
\text { dialami } & \end{array}$ \\
\hline 4 & $\mathrm{D} / \mathrm{L}$ & $\begin{array}{l}7 \\
\text { tahun }\end{array}$ & Kelas I & $\begin{array}{lr}\text { Cukup } & \\
\text { komunikatif, } \\
\text { bersedia } \\
\text { bercerita } & \text { tentang } \\
\text { dirinya } & \text { dan } \\
\text { kegiatan } & \text { sehari- } \\
\text { hari } & \text { yang } \\
\text { dilakukan } & \\
\end{array}$ & $\begin{array}{lr}\text { Tidak } & \text { mengerti } \\
\text { nama dan makna } \\
\text { peristiwa } & \text { kekerasan } \\
\text { seksual } & \text { yang } \\
\text { dialami } & \end{array}$ \\
\hline
\end{tabular}


Healthcare Nursing Journal Fakultas Ilmu Kesehatan UMTAS

E-ISSN : 2655-6812, Volume 2 Nomor 1, Agustus 2019

http://journal.umtas.ac.id/index.php/healtcare

\begin{tabular}{|c|c|c|c|c|c|}
\hline & & & & dengan ekspresif & \\
\hline 5 & $\mathrm{~K} / \mathrm{L}$ & $\begin{array}{l}7 \\
\text { tahun }\end{array}$ & Kelas I & $\begin{array}{l}\text { Banyak } \\
\text { menunduk, } \\
\text { bersedia } \\
\text { bercerita tentang } \\
\text { dirinya, namun } \\
\text { dengan jawaban } \\
\text { yang singkat }\end{array}$ & $\begin{array}{lr}\text { Tidak } & \text { mengerti } \\
\text { nama dan makna } \\
\text { peristiwa } & \text { kekerasan } \\
\text { seksual } & \text { yang } \\
\text { dialami } & \end{array}$ \\
\hline 6 & $\mathrm{~V} / \mathrm{L}$ & $\begin{array}{l}7 \\
\text { tahun }\end{array}$ & Kelas I & $\begin{array}{l}\text { Banyak } \\
\text { menunduk, } \\
\text { bersedia } \\
\text { bercerita tentang } \\
\text { dirinya, namun } \\
\text { dengan jawaban } \\
\text { yang singkat }\end{array}$ & $\begin{array}{l}\text { Mengerti apa nama } \\
\text { peristiwa kekerasan } \\
\text { yang dialami } \\
\text { Tidak mengerti } \\
\text { makna peristiwa } \\
\text { kekerasan seksual } \\
\text { yang dialami }\end{array}$ \\
\hline 7 & $\mathrm{AR} / \mathrm{L}$ & $\begin{array}{l}9 \\
\text { tahun }\end{array}$ & Kelas III & \begin{tabular}{l} 
Cukup \\
komunikatif, \\
bersedia \\
bercerita \\
dirinya $r$ dang \\
kegiatan sehari- \\
hari yang \\
dilakukan \\
\multicolumn{2}{l}{ dengan ekspresif }
\end{tabular} & $\begin{array}{l}\text { Mengerti apa nama } \\
\text { peristiwa kekerasan } \\
\text { yang dialami } \\
\text { Tidak mengerti } \\
\text { makna peristiwa } \\
\text { kekerasan seksual } \\
\text { yang dialami }\end{array}$ \\
\hline
\end{tabular}

Adapun dengan menggunakan

instrumen Anatomical Drawing, semua anak menandai bagian bokong (pantat) sebagai bagian tubuh yang menerima kekerasan seksual, artinya bagian tubuh tersebut, adalah bagian tubuh yang dijadikan pelaku sebagai sasaran untuk melakukan kekerasan seksual. Sementara dengan instrumen Gingerbread Figure, menunjukkan ada dua anak yang menandai bokongnya sebagai bagian tubuh yang masih sakit, sementara anak yang lain menandai bagian tubuh yang lain, ada yang di bagian kaki, tangan, dada, perut dan ada juga yang tidak menandai apa-apa di gambarnya.

\section{PEMBAHASAN}

Peristiwa kekerasan seksual, terutama pada anak akan menjadi stressor yang tidak dapat diatasi dan menimbulkan masalah dan gangguan perilaku di kemudian hari. Diantara gangguan tersebut adalah gangguan makan (bulimia atau anoreksia), masalah 
seksual, penganiayaan diri, bunuh diri, gejala somatik. kecemasan, gangguan penghargaan diri, atau depresi berkepanjangan. Sebagian besar korban kekerasan seksual juga menghadapi resiko terkena Posttraumatic Stress Disorder (PTSD) (Phebe, Handadari, 2012). Untuk bisa melanjutkan kehidupannya dengan sehat di kemudian hari, korban kekerasan seksual yang mengalami PTSD harus menerima dan menjalani serangkaian terapi, termasuk psikoterapi, meskipun tingkat PTSD masing-masing korban tidak sama. Korban yang mampu memulihkan dirinya dari PTSD akan mampu menjadi orang yang sehat dan mampu berfungsi secara sosial sebagaimana individu lain yang tidak pernah mengalami peristiwa kekerasan seksual. Proses pemulihan para korban akan sangat tergantung pada kualitas kepribadian korban tersebut. Mereka yang mampu mencari makna dalam setiap kejadian negatif yang dialami, tetap produktif, memiliki aktivitas yang dijalani setiap hari, memiliki cita-cita dan visi kedepan mengenai hidupnya, dan mampu menerima ataupun memaafkan apa yang sudah terjadi, akan bisa kembali menjalani kehidupannya dengan sehat, walaupun membutuhkan proses dan waktu untuk menjalaninya.

Pada korban anak-anak, pemulihan dan proses penyembuhan terhadap trauma yang dialami akan sangat tergantung pada sistem sosial yang terdekat dengan anak. Khususnya sistem yang bertanggung jawab terhadap kesejahteraan sosial anak, termasuk didalamnya pemerintah, masyarakat di sekitar anak tinggal dan tentu saja keluarganya (Brown, 2012). Sistem sosial inilah yang harus memutuskan apakah rumah tempat tinggal anak aman untuk terus ditinggali setelah kejadian, apakah anak perlu ditemani oleh pendamping selain orang tua saat berada di rumahnya, apakah anak perlu dipindahkan dari rumahnya dan dititipkan pada anggota keluarga lain yang dekat dengan anak secara emosional, atau perlukah anak dititipkan di panti atau rumah negara setelah kejadian?.

Pada penelitian ini, berdasarkan hasil asesmen PSC-17, semua korban menunjukkan adanya perubahan perilaku setelah kejadian, terutama perilaku yang termasuk kategori Internalizing berupa cemas dan depresi dan Externalizing berupa tingkah laku 
melanggar aturan dan melanggar hakhak orang lain. Dengan kondisi ini, bisa dimaknai bahwa pasca kejadian, perilaku anak berubah menjadi bukan dirinya yang semula. Brown (2012) menyatakan bahwa objek asesmen pada anak yang menjadi korban kekerasan seksual, utamanya di tekankan pada adakah perubahan perilaku anak pada: 1. Masalah tidur 2. Kualitas bermain, 3. Mandi dan aktivitas di toilet 4. Rasa takut/fobia 5. Perilaku kompulsif dan 6. Kecemasan berpisah. Aspek-aspek ini sejalan dengan item-item yang ditanyakan dalam PSC-17. Dan perubahan perilaku tersebut memang diakui oleh para orang tua muncul dan ditunjukkan oleh para korban menjadi lebih banyak frekuensinya setelah mereka mengalami kekerasan seksual.

Berdasarkan wawancara dengan para korban, tidak semua anak memahami peristiwa kekerasan yang dialami, sebagai peristiwa traumatik. Mereka menyatakan tidak tahu itu peristiwa apa, bahwa hal tersebut sesuatu yang biasa saja seperti saat mereka bermain bola atau melakukan permainan yang lain, beberapa diantara mereka saat ditanya, menceritakan pertistiwa tersebut sambil tertawa-tawa dan saling menunjuk satu sama lain seperti sedang bercanda.
Darkness To The Light, sebuah organisasi nirlaba yang peduli pada kasus-kasus kekerasan seksual yang menimpa anak-anak, pada satu publikasinya mengatakan bahwa, sebanyak $38 \%$ anak-anak yang mengalami kekerasan seksual, seringkali tidak sadar bahwa mereka sudah mengalami tindakan kekerasan, bahkan sampai pada akhir pengusutan ada anak-anak yang memang tidak pernah tahu bahwa mereka telah mengalami kekerasan seksual. Membiarkan anak-anak tidak tahu bahwa mereka mengalami kekerasan seksual dikaitkan dengan usaha untuk melindungi anak-anak dan menjaga privasi keluarga serta identitas mereka. Biasanya untuk tujuan inilah kasus yang mereka alami sengaja tidak diungkap secara tuntas.

Terkait dengan kondisi korban secara fisik, dari tujuh orang korban, hanya dua korban terakhir, yaitu $\mathrm{V}$ dan $\mathrm{AR}$ yang masih menandai bagian bokongnya sebagai bagian tubuh yang terasa sakit, disertai tanda bahwa perut dan dadanya juga masih terasa sakit. Hal ini mungkin disebabkan karena mereka baru dua hari mengalami peristiwa kekerasan seksual, sebelum dibawa menemui peneliti. Adapun lima 
korban yang lain sudah tidak merasakan sakit di area tersebut, karena peristiwa tersebut sudah relatif lama mereka alami, ada yang sudah dua minggu hingga 1 bulan. Meski demikian, beberapa diantaranya ada yang menandai bagian tubuh yang lain yang mereka rasakan sakit. Bagian tubuh lain yang mereka tandai selain bokong, adalah kaki, tangan, dan punggung yang mereka akui terasa sakit karena aktivitas mereka saat bermain bola ataupun berolah raga dan aktivitas yang lainnya, tidak terkait dengan peristiwa kekerasan seksual yang mereka alami.

Reaksi berupa kesakitan secara fisik pada peristiwa kekerasan seksual pada anak, terutama pada area genitalia, biasanya akan mereka rasakan dalam beberapa hari, terutama saat area tersebut terpapar sabun saat mandi atau mereka melakukan aktivitas buang air besar dan membersihkannya. Seiring dengan mengeringnya luka, jika ada luka ataupun menghilangnya memar akibat gesekan benda tumpul, rasa sakit tersebut akan berkurang ataupun hilang, kecuali jika kekerasan seksual berlangsung dan terjadi berulang-ulang. Pada korban yang diteliti, frekuensi korban mengalami kekerasan bervariasi antara satu sampai dua kali, karena kasus sudah terlanjur terbongkar, sehingga pelaku tidak memiliki kesempatan untuk mengulanginya lagi. Frekuensi yang sedikit, yaitu satu atau dua kali, memungkinkan mekanisme tubuh korban dalam memulihkan luka sendiri menjadi lebih cepat dan para korban lebih mudah untuk melupakan rasa sakitnya secara fisik. Hal ini menjelaskan mengapa hasil pada instrumen gingerbread figure, sebagian besar korban sudah tidak menandai bagian bokong sebagai bagian tubuh yang mereka rasakan sakit kecuali dua korban terakhir, meski pada anatomical drawing semua korban menandai bokong adalah bagian tubuh yang menjadi sasaran kekerasan seksual oleh pelaku.

\section{KESIMPULAN}

Berdasarkan hasil penelitian yang telah dilakukan, dapat disimpulkan bahwa tujuh anak yang mengalami kekerasan seksual, menunjukkan adanya perubahan perilaku sebagai gejala adanya gangguan kesehatan mental akibat peristiwa yang dialaminya. Adapun dua anak yang masih menunjukkan tingginya frekuensi perubahan perilaku terkait gejala gangguan kesehatan mental, karena 
baru dua hari mengalami peristiwa tersebut, sehingga orang tua masih menemukan banyak perubahan perilaku akibat peristiwa tersebut, dan anak secara fisik masih bisa menghayati dan merasakan rasa sakitnya ditubuh mereka.

Dengan adanya fakta ini seluruh pihak yang terkait dengan kesejahteraan dan kesehatan mental korban, yaitu orang tua, guru, orang-orang terdekat, masyarakat, dan utamanya pemerintah, perlu terus memperhatikan secara intensif tumbuh kembang anak-anak tersebut, mengobservasi dan memahami reaksi emosinya, melakukan kontrol terhadap perilakunya, dan memberi fasilitas serta menyediakan sarana dan prasarana yang mendukung untuk tercapainya kesejahteraan dan kesehatan mental mereka. Diharapkan dengan hal tersebut anak-anak yang telah menjadi korban ini tidak terjerumus pada perilaku seksual yang menyimpang, sebagai akibat dari peristiwa yang mereka alami, hingga mereka dewasa. Pada dua orang anak yang menunjukkan skor yang relatif tinggi diatas cut off yang menandai banyaknya gejala gangguan perilaku akibat peristiwa tersebut, hendaknya ditindak lanjuti dengan pendampingan lebih intensif khususnya oleh P2TP2A Kabupaten Tasikmalaya dan para kader di desa masing-masing dengan dukungan dari seluruh stakeholder dan pemerintah terkait. Pendampingan tersebut bisa diberikan kepada orang tua korban, maupun kepada korban secara langsung, baik berupa terapi, edukasi, pendampingan secara emosional dan dukungan yang lain.

\section{KETERBATASAN}

Karena keterbatasannya, baik dalam metode, interpretasi kondisi subjek dan aspek lainnya yang terkait, hasil penelitian ini tidak bisa dijadikan generalisasi untuk penelitian sejenis yang dilakukan oleh peneliti lainnya. Salah satu keterbatasan dalam penelitian ini adalah tingkat pendidikan para orang tua dan korban yang rendah, sehingga kepekaan ataupun pemahaman mereka terhadap perubahan-perubahan perilaku pada diri korban diakui kurang akurat, hal ini diakui mereka karena mereka lupa atau karena kurang memperhatikan. Dengan demikian, hasil penelitian ini sangat tergantung pada faktor subyektivitas korban dan para orang tuanya dalam menjawab pernyataan dalam setiap item PSC-17, juga dalam memberikan jawaban saat 
Healthcare Nursing Journal Fakultas Ilmu Kesehatan UMTAS

E-ISSN : 2655-6812, Volume 2 Nomor 1, Agustus 2019

http://journal.umtas.ac.id/index.php/healtcare

wawancara pada proses konseling psikologi.

\section{REFERENSI}

A Handbook for Caregivers of Sexually Abuse

Children,

https://www.athenscac.org/upload/docu

ments/athens-cac-handbook.pdf di akses

pada 10 Agustus 2019

Brown, Paris-Goodyear. 2012.

Handbook of Child Sexual Abuse:

Identification Assessment and

Treatment, New Jersey: Jhon Wiley and

Sons

Harahap, Dwi Fachri, Damayanti Rusli

Sjarif, Soedjatmiko, Dwi Putro Widodo,

Mayke S. Tedjasaputra. 2010.

Identification of Emotional and

Behavior Problems in Obese Children

Using Child Behavior Checklist (CBCL)

and 17-Items Pediatric Symptom

Chekclist (PSC-17). Jurnal Pediatrica

Indonesiana Vol 50, No.1, Januari 2010.

Illenia S, Phebe, Woelan Handadari,

Pemulihan Diri Pada Korban

Kekerasan Seksual Jurnal Insan Media

Psikologi Volume 13 No.02 Agustus

2011.

Sari, Ratna, Soni Ahmad Nulhakim dan Maulana Irfan. 2015. Pelecehan
Seksual Pada Anak, Prosiding KS: Riset dan PKM Volume 2 No. 1 tahun 2015

fisip.unpad.ac.id/jurnal/index.php/prosi ding/article/view/78 diakses pada 8

Agustus 2019

Wahyuni, Hera. 2016. Faktor Resiko Gangguan Stres Pasca Trauma pada Anak Korban Pelecehan Seksual. Jurnal Ilmiah Kependidikan Khazanah Kependidikan Volume X No. 1 September 2016.

http://www.depkes.go.id/download.php $\underline{\text { ?file }=\text { download/pusdatin/infodatin/Keke }}$ rasan-terhadap-anak.pdf. diakses pada 13 Agustus 2019

https://www.d2l.org/wpcontent/uploads/2017/01/all_statistics 20150619.pdf diakses pada 10 Agustus 2019 